\title{
Evaluation of milk composition and fresh soft cheese from an intensive silvopastoral system in the tropics
}

\author{
Asmaa Hosny Mohammed Mohammed ${ }^{1,2}$. \\ Carlos Fernando Aguilar-Pérez ${ }^{1}$. \\ Armín Javier Ayala-Burgos ${ }^{1}$. \\ María Benedicta Bottini-Luzardo ${ }^{1}$. \\ Francisco Javier Solorio-Sánchez ${ }^{1}$. \\ Juan Carlos Ku-Vera ${ }^{1}$
}

Received: 7 May 2015 / Revised: 20 July 2015 / Accepted: 24 July 2015 /

Published online: 17 August 2015

(C) INRA and Springer-Verlag France 2015

\begin{abstract}
Intensive silvopastoral system (ISS) is a successful sustainable grazing system for dual-purpose cattle with growing adoption in the tropics; however, there is a concern on the quality of dairy products from this system. The aim of this study was to compare the ISS with the traditional monoculture system (MS) in terms of milk composition, soft cheese composition and yield, and the sensory acceptability of cheese during two seasons of a tropical area in Mexico. Twenty-four cows at the first 3 months postpartum were allocated evenly to two groups. The cows in ISS grazed in paddocks of Leucaena leucocephala associated with Cynodon nlemfuensis whereas the cows in MS grazed in C. nlemfuensis. Milk samples were collected weekly during the rainy and dry seasons for chemical analysis and fresh soft cheese making. The cheese was analyzed chemically, and cheese acceptability was evaluated for the sensory attributes of appearance, texture, flavor, color, and overall acceptability. Milk percentages of fat, protein, SNF, and lactose did not differ significantly between systems being, 3.5, 3.0, 8.1, and 4.4 in ISS and 3.6, 2.9, 8.0, and 4.4 in MS, respectively. Similar results were obtained for cheese content of fat/DM and protein/DM. In the rainy season, adjusted cheese yield from ISS (24.2\%) was higher compared with MS (20.8\%). Cheese texture in the dry season showed more acceptability for ISS. This study provide absence of adverse effect of ISS on milk and cheese composition; moreover, ISS improve the yield and acceptability of soft cheese.
\end{abstract}

Asmaa Hosny Mohammed Mohammed

asmaa_moneeb@yahoo.com

1 Facultad de Medicina Veterinaria y Zootecnia, Universidad Autónoma de Yucatán, Carretera Mérida-Xmatkuil km 15.5, Apartado 4-116 Itzimná, C. P. 97100 Mérida, Yucatán, México

2 Faculty of Agriculture, Department of Dairy Science, Assiut University, Assiut, P. C. 71526, Egypt 
Keywords Milk composition · Fresh soft cheese - Intensive silvopastoral system · Cheese acceptability

\section{Introduction}

The trade in dairy products is expected to grow for the coming decade due to the increased human demand (OECD/FAO 2014). In human nutrition, milk and milk products are important, particularly cheese which is the most consumed milk-derived product. World consumption of cheese was 20,425 thousand tons in 2012 and expected to increase to 23,387 thousand tons in 2022 (OECD/FAO 2013). The largest trade of milk and dairy product consumption is in the form of fresh dairy products, representing up to $70 \%$ of total milk production of the world (OECD/FAO 2014). Fluid milk production in Mexico reached 11,129,921 thousand liters in 2014 (LACTODATA 2015), and $15 \%$ of this production is used for fresh type cheeses (SAGARPA/SIAP 2014).

In the tropics, milk production is mainly from the "dual-purpose systems", a system to produce milk (daily milking) and meat (calf after weaning) in the same herd (Rojo-Rubio et al 2008). Dual-purpose system is characterized by the use of crosses from Bos taurus $\times$ Bos indicus breeds and is based on grazing tropical pastures, which provide low-cost feeds to cattle (Pedraza-Beltrán et al 2012). It is well known that weather conditions determine seasonal variations in milk yield and composition, and this fact can modify cheese quality (FAO 2013; Solís-Méndez et al. 2013).

Intensive silvopastoral system (ISS) have been proposed as a sustainable strategy in the tropics to increase the availability and quality of forage across the year for meat and milk cattle production (Echevarría et al 2013). These type of systems are defined as intensive because of the sowing of a high density of forage shrubs such as Leucaena leucocephala (more than 10,000 plants.ha ${ }^{-1}$ ) associated with improved grasses, e.g., Panicum maximum and Cynodon nlemfuensis among others (Cuartas-Cardona et al 2014). L. leucocephala is a tropical legume that has been successfully used in ISS, because of its nutritional value, adaptation to tropical conditions, as well as its environmental services such as carbon capture and nitrogen fixation (Cuartas-Cardona et al 2014). The association leucaena/grass support higher levels of milk production (Hernández Rodríguez and Ponce Ceballo 2004) and offers the possibility to certify milk and cheese as organic products ( Nahed-Toral et al 2013) with improved prices (Von Borell and Sørensen 2004; Solís-Méndez et al 2013). Sensory characteristics of cheeses can be defined as the human responses to perceptions of stimuli that are in the cheeses (Delahunty and Drake 2004). The nature of ingested forages by ruminants influence milk constituents and the sensory properties of dairy products; this is the case of carotenoids, responsible for the yellow color of dairy products (Coulon and Priolo 2002; Larsen et al 2013). Additionally, phenolic compounds such as indole and skatole can increase in milk when cows are grazing on pasture, which could affect the flavor of dairy products (O'Connell and Fox 2001). Actually, there is no clear view of the effect of consuming leucaena by the cows on the sensory properties of the produced milk or cheese. Stobbs and Fraser (1971) reported that leucaena can cause adverse effects on the flavor and odor in the milk, while in other study by Morillo and Faría-Mármol (1996), they did not realize this problem. 
The objective of this study was to evaluate the chemical composition of the milk and the soft cheese as well as the cheese yield and acceptability from an intensive silvopastoral system based on L. leucocephala and C. nlemfuensis, during the rainy and the dry season in the tropics.

\section{Materials and methods}

\subsection{Location and duration of the study}

The study had two periods: the period I was the rainy season (July to October 2013) and the period II was the dry season (November 2013 to April 2014). It was carried out in the Campus de Ciencias Biológicas y Agropecuarias of the Universidad Autónoma de Yucatán (CCBA-UADY), Mexico, located at the east of the Yucatan Peninsula between the latitudes $16^{\circ} 06^{\prime}$ and $21^{\circ} 37^{\prime}$ north and longitudes $87^{\circ} 32^{\prime}$ and $90^{\circ} 23^{\prime}$ east. The region has a sub-humid tropical climate, with an average annual rainfall of $953 \mathrm{~mm}$. The annual mean of temperature is $26.5^{\circ} \mathrm{C}$, with maximum and minimum ranges from 36 to 40 and from 14 to $16^{\circ} \mathrm{C}$, respectively (García 1988). Temperatures and rainfall were registered during the experiment and were taken from the microclimatic station at the CCBA-UADY (Fig. 1).

\subsection{Animals management and treatments}

There were used twenty four crossbred of Holstein and Brown Swiss $\times$ Zebu cows with European genes ranging from 50 to $75 \%$. All the cows were multiparous ( $\geq 3$ calvings) in the early postpartum ( $<3$ months). The mean body weight was $526 \pm 56 \mathrm{~kg}$ and the body condition score was $6 \pm 0.3$, according to the scale 1 (very thin) to 9 (very fat) (Ayala et al 1992). Treatments were established based on the feeding management as follows: the control group was the monoculture system (MS). This group $(n=12)$ grazed in a paddocks of Stargrass (C. nlemfuensis) with a stocking rate of 2 AU.ha $^{-1}$ ([AU] 1 animal unit $=450 \mathrm{~kg}$ live weight). The cows of this treatment were

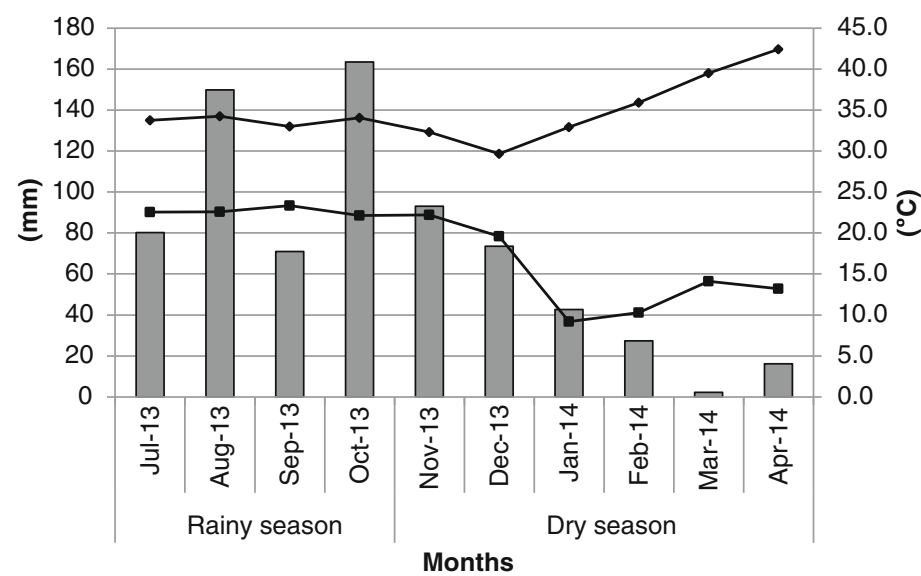

$\square$ Rainfall (mm)

$\rightarrow$ Tem $\operatorname{Max}\left({ }^{\circ} \mathrm{C}\right)$

$\rightarrow-\operatorname{Tem} \operatorname{Min}\left({ }^{\circ} \mathrm{C}\right)$

Fig. 1 Temperature and rainfall during the experimental period 
supplemented at milking with a concentrate based on ground corn grain $60 \%$, soybean meal $30 \%$, and soybean husks $10 \%$.

The second treatment was the ISS: this group $(n=12)$ grazed in mixed plots of L. leucocephala $\left(36,000\right.$ leucaena plants.h $\left.{ }^{-1}\right)$ and Stargrass (C. nlemfuensis) at a stocking rate of $2.4 \mathrm{AU}_{\mathrm{h}} \mathrm{h}^{-1}$. The cows in this system were supplemented at milking with ground sorghum grain only.

The grazing times in both groups of cows were from 1700 to 0500 hours and from 0800 to 1300 hours. The two grazing systems had irrigation regularly during the dry season and during the other season as required. In order to allocate the supplement, records of milk yield of cows were checked and dry matter intake was previously estimated in the herd (Bottini-Luzardo 2015). The supplement in the two systems were offered to the animals to satisfy the protein and energy requirements (AFRC 1993). The concentrate and sorghum were offered in two equal portions at milking (0600 and 1500 hours). It was verified that all cows consumed the total amount of the respective supplement. The milking was mechanically, and the calf was used for few minutes before to stimulate the cow to let milk down. After milking, the calf was allowed to stay with the cow for $30 \mathrm{~min}$, to take residual milk. Milk yield was recorded every month individually for the cows in each system. Samples of forage and supplements were taken monthly and analyzed for dry matter (AOAC 2012), crude protein by total nitrogen determination according to Dumas method using a LECO C'N analyzer (LECO Corporation 2014) (\% protein $=\% \mathrm{~N} \times 6.25)$, and metabolizable energy was estimated according to MAFF (1975). Acid detergent fiber and neutral detergent fiber in forage samples were analyzed according to Van Soest et al (1991). Ether extract and ash were determined in the supplements with the methods of Tejada (1983) and AOAC (2012), respectively. The chemical composition of the forages and supplements is shown in Table 1. Grass dry matter intake was measured according to Dove and Mayes (1991). Table 2 summarizes the records of feed intake of the cows grazing the two systems during the two seasons.

Table 1 Chemical composition (dry matter basis) of feedstuffs used for cows grazing a monoculture system (MS) and an intensive silvopastoral system (ISS)

\begin{tabular}{|c|c|c|c|c|c|}
\hline & \multicolumn{2}{|l|}{ MS } & \multicolumn{3}{|l|}{ ISS } \\
\hline & Concentrate & Stargrass & Sorghum & Stargrass & L.leucocephalo \\
\hline DM \% (fresh matter basis) & 90 & 36.1 & 90 & 30.1 & 33.8 \\
\hline $\mathrm{CP} \%$ & 12.4 & 6.2 & 8.6 & 9.9 & 15.3 \\
\hline $\mathrm{ADF} \%$ & - & 37.0 & - & 36.2 & 24.8 \\
\hline NDF \% & - & 50.7 & - & 50.2 & 41.1 \\
\hline $\mathrm{CF} \%$ & 10.1 & - & 2.2 & - & - \\
\hline EE \% & 1.5 & - & 2.0 & - & - \\
\hline Ash \% & 3.8 & - & 1.4 & - & - \\
\hline ME (MJ/kg DM) & 12.6 & 8.9 & 13.8 & 9.0 & 11.2 \\
\hline
\end{tabular}

Adapted from Bottini-Luzardo (2015)

$D M$ dry matter, $C P$ crude protein, $A D F$ acid detergent fiber, $N D F$ neutral detergent fiber, $C F$ crude fiber, $E E$ ether extract, $M E$ metabolizable energy 
Table 2 Daily dry matter intake $\left(\mathrm{kg} \cdot \mathrm{cow}^{-1}\right.$.day ${ }^{-1}$ ) of dual-purpose cows grazing a monoculture system (MS) and an intensive silvopastoral system (ISS) during the rainy and dry seasons

\begin{tabular}{llllll}
\hline Season & \multicolumn{2}{l}{ Rainy } & & \multicolumn{2}{c}{ Dry } \\
\cline { 2 - 3 } \cline { 5 - 6 } System & MS & ISS & & MS & ISS \\
\hline Sorghum & - & 4.79 & & - & 7.5 \\
Concentrate & 5.5 & - & 2.9 & - \\
L. leucocephala & - & 5.38 & & - & 6.3 \\
Stargrass & 7.3 & 3.71 & 7.2 & 2.8 \\
\hline
\end{tabular}

Adapted from Bottini-Luzardo (2015)

\subsection{Milk sampling and chemical analysis}

Milk samples from each treatment (three liters) were obtained every week at the morning and afternoon milkings. Milk obtained from the afternoon milking was refrigerated at $5{ }^{\circ} \mathrm{C}$ and was then mixed thoroughly with milk from the morning milking to get a homogeneous sample per treatment. These samples were transferred to the laboratory for chemical analysis and for cheese making. There was taken $200 \mathrm{ml}$ for milk analysis and 4 liters for cheese making. The numbers of samples obtained from each system were 42 (weeks) in total. Milk analysis for percentages of fat, total protein, lactose, and minerals were performed weekly during the two seasons using an automatic milk analyzer (Lactoscan MCC, Milkotronic 19944, Bulgaria). The equipment was calibrated for fat by the Gerber method (Kleyn et al 2001) and for protein by total nitrogen determination, according to the Dumas method using a LECO C'N analyzer (LECO Corporation 2014). Percentage of protein was expressed as: $\% \mathrm{~N} \times 6.38$. $\mathrm{pH}$ in milk was measured using a $\mathrm{pH}$ meter (Hanna instrument $\mathrm{pHep}{ }^{\circledR} \mathrm{HI} 98107$ ), which was calibrated with standard buffer solutions of $\mathrm{pH} 4.0$ and 7.0.

\subsection{Cheese manufacture}

Fresh soft cheese (Domiati type) was made according to the method of Mehaia (2006) with modifications: milk was salted with sodium chloride at $3 \%(w / w)$, pasteurized at $73{ }^{\circ} \mathrm{C}$ for $15 \mathrm{~s}$, and cooled to $40^{\circ} \mathrm{C}$. Then, microbial rennet (CUAMIX, CHR-HANSEN, Mexico) was added and mixed thoroughly. The milk was maintained at $40{ }^{\circ} \mathrm{C}$ until coagulation. After that, the curd was scooped into cheese cloth, drained for 2 days in a cooler at $5{ }^{\circ} \mathrm{C}$, then cheese was taken out of the cheese cloth and weighed. A cheese sample of $200 \mathrm{~g}$ was taken for chemical analyses and frozen at $-18^{\circ} \mathrm{C}$ until analyses. For sensory evaluation, fresh samples of cheese were taken at the end of every season.

\subsection{Chemical analysis of the cheese}

Moisture (M) content was determined by drying 2 to $3 \mathrm{~g}$ of cheese at $105{ }^{\circ} \mathrm{C}$ until constant weight (AOAC 2012). Cheese dry matter (DM) was calculated as $100-\%$ moisture. Cheese fat content was measured using the Gerber method (AOAC 2012). Fat in dry matter (Fat/DM \%) was calculated by the formula Fat/DM $\%=($ Cheese fat 
$\% \times 100) /$ Cheese DM \%. Salt content of cheese was determined using the Mohr titration method (Nielsen 2010). Salt in moisture (Salt/M\%) was calculated by the formula Salt $/ \mathrm{M} \%=($ Cheese salt $\% \times 100) /$ Cheese $\mathrm{M} \%$. Cheese total nitrogen determination was made by the automated Dumas dry combustion method using a LECO C-N analyzer (LECO Corporation 2014). Percentage of protein was expressed as $\% \mathrm{~N} \times$ 6.38. Protein in dry matter (Protein/DM \%) was calculated by the formula Protein/DM $\%=($ Cheese protein $\% \times 100) /$ cheese DM $\%$. The ashes were determined by incineration of about $3 \mathrm{~g}$ sample in a furnace oven at $550{ }^{\circ} \mathrm{C}$ for $4 \mathrm{~h}$ (AOAC 2012).

\subsection{Cheese yield calculations}

Actual cheese yields were calculated as the weight of cheese divided by the weight of milk used and expressed as $\mathrm{kg} .100 \mathrm{~kg}^{-1}$ milk. The actual cheese yields varied markedly especially in soft cheese due to the variations in moisture and salt content as reported by Mehaia (2006); therefore, cheese yields were adjusted to a standard moisture and salt content for statistical analysis using the average moisture and salt content of the soft cheese obtained in this experiment (70.48 and 2.69\%, respectively). Adjusted cheese yield was calculated by the following formula Mehaia (2006):

Adjusted yield $\%=$ actual cheese yield $\% \times(100-($ actual cheese moisture $\%+$ actual cheese salt $\%))$

$\div(100-(70.48+2.69))$

\subsection{Sensory evaluation of the cheese}

Cheese sensory evaluation was performed by 15 test panelists familiar with Domiati cheese. There was used a scoring test with the aid of a nine point hedonic scale (where $9=$ like extremely, $5=$ neither like nor dislike, and $1=$ dislike extremely) to determine the cheese acceptability. The sensory attributes of appearance, texture, flavor, color, and overall acceptability were examined as described by Mehaia (2006). Cheese samples were randomly coded and presented to each panelist at $20{ }^{\circ} \mathrm{C}$. Data collected from panelists were subjected to statistical analysis.

\subsection{Experimental design and statistical analysis}

A $2 \times 2$ factorial design with season and system of production as fixed factors was used. The response variables (milk and cheese composition) were analyzed by analysis of variance using a two-way ANOVA with the model $Y_{i j k}=\mu+T_{i}+S_{j}+(T S)_{i j}+\varepsilon_{i j k}$, where $Y_{i j k}$ is the dependent variable, $\mu$ is the general mean, $T_{i}$ is the effect of $i$ th system $(i=\mathrm{MS}, \mathrm{ISS}), S_{j}$ is the effect of $j$ th season $\left(j=\right.$ rainy, dry), $(T S)_{i j}$ is the effect of the interaction between system and season, and $\varepsilon_{i j k}$ is the residual error, using the GLM procedure of SPSS Statistics 22 (SPSS for windows 2013). Interaction effect was removed from the final model when it was not significant $(P>0.05)$, and the principle effect was evaluated. For the sensory analysis, one-way ANOVA was used for every season separately and the system of production as fixed factor. In addition, Pearson's correlation coefficients were calculated between milk components and the adjusted cheese yield separately for the two systems. 


\section{Results}

\subsection{Milk composition}

The composition of the milk from the evaluated systems is shown in Table 3. It was not found any effect of the system on milk composition. Percentages of fat, protein, solids not fat (SNF), total solids, lactose, and minerals were all significantly higher $(P<0.05)$ in the dry season for the MS and ISS. The $\mathrm{pH}$ was higher $(P<0.05)$ in the milk from the rainy season than that of the dry season. Interactions between season and system concerning to all milk compositional variables were not significant (Table 3).

\subsection{Fresh soft cheese composition}

Table 4 shows the chemical composition and the adjusted yield of fresh soft cheese made in the rainy and in the dry seasons from MS and ISS. No significant differences $(P>0.05)$ were detected between systems regarding the cheese percentage of DM, fat/DM, protein/DM, salt/M, ash, and cheese yield adjusted. Cheese made during the dry season showed higher content $(P<0.05)$ of fat/DM, protein/ $\mathrm{DM}$, and cheese yield adjusted than the cheese made during the rainy season.

For cheese yield adjusted, a significant interaction $(P<0.05)$ between season and system was observed. The source of the interaction is shown in Fig. 2. The cheese yield was higher for ISS during the rainy season comparing with MS in the same season $(P<0.05)$, while no difference between systems was found in the dry season. There were no differences for season or for system regarding to the cheese salt/M or ash percentage $(P>0.05)$.

Table 3 Milk yield (L.cow ${ }^{-1}$.day ${ }^{-1}$ ) and milk composition (mean \%) of dual purpose cows as affected by grazing season and system

\begin{tabular}{|c|c|c|c|c|c|c|c|c|}
\hline \multirow{2}{*}{$\begin{array}{l}\text { Season } \\
\text { System }\end{array}$} & \multicolumn{2}{|l|}{ Rainy } & \multicolumn{2}{|l|}{ Dry } & \multirow[t]{2}{*}{ SEM } & \multicolumn{3}{|l|}{$P$} \\
\hline & $\begin{array}{l}\text { MS } \\
(n=16)\end{array}$ & $\begin{array}{l}\text { ISS } \\
(n=16)\end{array}$ & $\begin{array}{l}\text { MS } \\
(n=26)\end{array}$ & $\begin{array}{l}\text { ISS } \\
(n=26)\end{array}$ & & Season & System & Interaction \\
\hline Milk yield & 16.3 & 10.1 & 14.2 & 18.5 & & & & \\
\hline Fat & 3.4 & 3.3 & 3.7 & 3.6 & 0.05 & $* *$ & NS & NS \\
\hline Protein & 2.9 & 2.9 & 3.0 & 3.0 & 0.01 & $* * *$ & NS & NS \\
\hline SNF & 7.9 & 7.9 & 8.1 & 8.2 & 0.03 & $* * *$ & NS & NS \\
\hline Total solids & 11.2 & 11.3 & 11.8 & 11.8 & 0.07 & $* * *$ & NS & NS \\
\hline Lactose & 4.3 & 4.4 & 4.5 & 4.5 & 0.02 & $* * *$ & NS & NS \\
\hline Minerals & 0.64 & 0.65 & 0.66 & 0.67 & 0.003 & $* * *$ & NS & NS \\
\hline $\mathrm{pH}$ & 6.8 & 6.8 & 6.7 & 6.6 & 0.01 & $* * *$ & NS & NS \\
\hline
\end{tabular}

$P$ statistical significance, NS nonsignificant, MS monoculture system, ISS intensive silvopastoral system, $n$ number of the weeks, $S N F$ solids not fat, $S E M$ standard error of mean

$* P<0.05 ; * * P<0.01 ; * * * P<0.001$ 
Table 4 Fresh soft cheese composition and adjusted yield (mean \%) as affected by grazing season and system

\begin{tabular}{|c|c|c|c|c|c|c|c|c|}
\hline \multirow{2}{*}{$\begin{array}{l}\text { Season } \\
\text { System }\end{array}$} & \multicolumn{2}{|l|}{ Rainy } & \multicolumn{2}{|l|}{ Dry } & \multicolumn{4}{|l|}{$P$} \\
\hline & $\begin{array}{l}\text { MS } \\
(n=16)\end{array}$ & $\begin{array}{l}\text { ISS } \\
(n=16)\end{array}$ & $\begin{array}{l}\text { MS } \\
(n=26)\end{array}$ & $\begin{array}{l}\text { ISS } \\
(n=26)\end{array}$ & SEM & Season & System & Interaction \\
\hline $\mathrm{DM}$ & 26.4 & 27.5 & 31.1 & 30.8 & 0.45 & $* * *$ & NS & NS \\
\hline Fat/DM & 41.6 & 40.8 & 46.7 & 44.9 & 0.51 & $* * *$ & NS & NS \\
\hline Protein/DM & 32.7 & 33.1 & 34.9 & 36.4 & 0.41 & $* * *$ & NS & NS \\
\hline Salt/M & 3.7 & 3.9 & 3.8 & 3.8 & 0.03 & NS & NS & NS \\
\hline Ash & 3.4 & 3.5 & 3.5 & 3.7 & 0.07 & NS & NS & NS \\
\hline Cheese yield adjusted & 20.8 & 24.2 & 24.7 & 23.9 & 0.34 & $* *$ & NS & $* *$ \\
\hline
\end{tabular}

$P$ statistical significance, $N S$ nonsignificant, $M S$ monoculture system, ISS intensive silvopastoral system, $n$ number of the weeks, $D M$ dry matter, $M$ moisture, SEM standard error of mean

$* P<0.05 ; * * P<0.01 ; * * * P<0.001$

\subsection{Correlation between milk components and fresh soft cheese yield}

Table 5 shows the correlation coefficients between the major milk components and the adjusted fresh soft cheese yield from MS and ISS. In MS, milk fat and total solids were highly positively correlated with cheese yield adjusted $(r=0.71$ and 0.73 , respectively). Protein content and SNF were also positively correlated with the adjusted soft cheese yield, but with a lower correlation value $(r=0.38$ for the both components). Similarly, lactose and minerals presented a low correlation value of 0.36 and 0.34 , respectively.

In ISS, fat and total solids were the components with higher correlations with the adjusted cheese yield $(P<0.01)$ with values of 0.64 and 0.71 , respectively. Milk protein, SNF, lactose, and minerals had lower correlation values with the adjusted cheese yield, being $0.5,0.49,0.49$, and 0.45 , respectively.

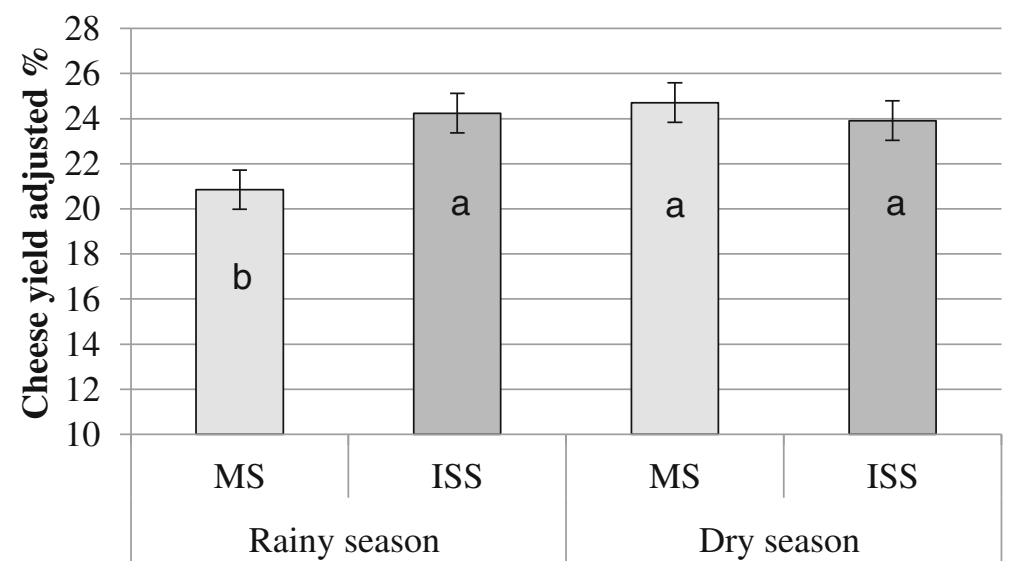

Fig. 2 Effect of system and season on the fresh soft cheese yield adjusted \%. Different letters $(a, b)$ are significantly different $(P<0.05) . M S$ monoculture system, ISS intensive silvopastoral system 
Table 5 Pearson correlation coefficients between major milk chemical components and fresh soft cheese yield from the intensive silvopastoral system (ISS) and monoculture system (MS)

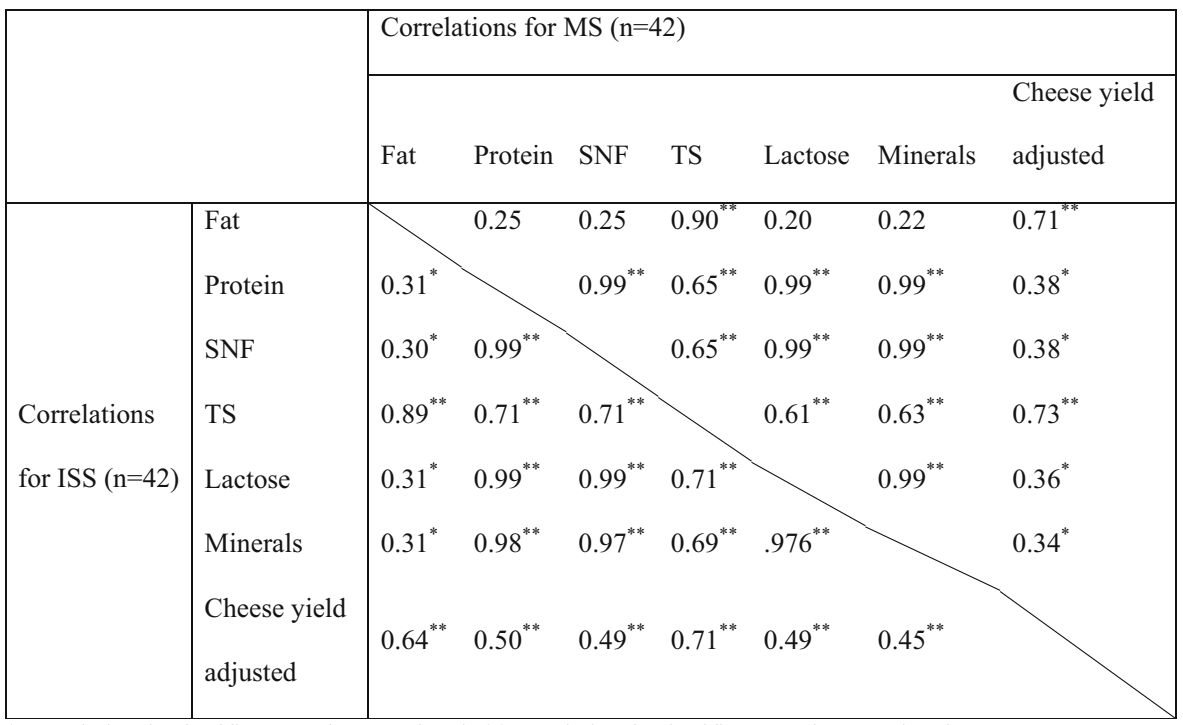

*Correlation is significant at the 0.05 level; **correlation is significant at the 0.01 level $n$ number of the weeks, $S N F$ solids not fat, TS total solids

\subsection{Sensory evaluation of fresh soft cheese}

Results of the sensory evaluation for fresh soft cheese from MS and ISS during the rainy and the dry season are shown in Fig. 3. There were no significant differences in all the sensory attributes of the cheese from MS and ISS in the rainy season. Similar results were found in the cheese from the dry season except a significant better acceptability for texture $(P<0.05)$ was found in the cheese from ISS.

Rainy

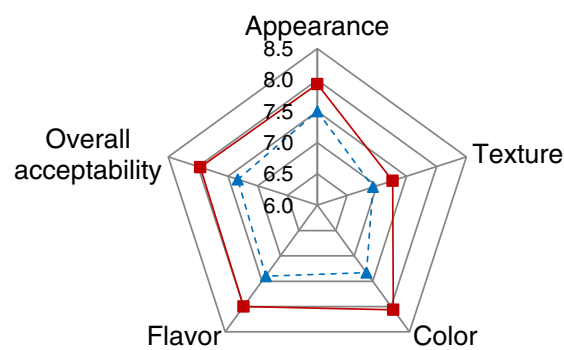

Dry

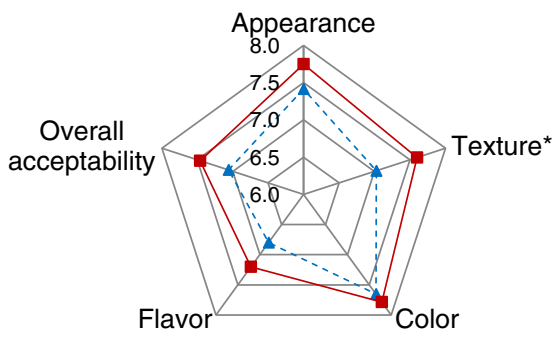

--- MS $\longrightarrow$ ISS

Fig. 3 Sensory scores of fresh soft cheese made in monoculture system (MS) and intensive silvopastoral system (ISS) during the rainy and dry season. $* P<0.05$ 


\section{Discussion}

\subsection{Milk composition}

Concerning to milk fat, protein, and lactose, similar results were found in a previous study with similar experimental conditions by Peniche-González et al. (2014). Those authors suggested that the absence of difference in milk composition between treatments could have been due to a similar supply of milk precursors to the mammary gland of the cows. Our results also are in agreement with Solís-Méndez et al. (2013) for the content of protein, lactose, and $\mathrm{pH}$, and with the findings of Faría-Mármol et al. (2007) who did not find significant differences in milk fat or milk protein percentage when 50 to $75 \%$ of concentrate feed was replaced by grazing a leucaena bank for 2 h.day ${ }^{-1}$.

In general, milk components were higher in the dry season than the rainy season for the two systems. In the MS, the increase in milk components can be associated to the reduction in milk yield in the dry season, resulting in a concentration of milk components (Todaro et al 2014). In the ISS, the higher milk components in the dry season could not be explained by a concentration effect, because milk yield was higher during this season. This result could be related to the higher intake of L. leucocephala and the lower intake of stargrass during the dry season (Table 2), which could lead to a better fiber digestibility of the diet considering the lower contents of ADF in leucaena in comparison to the stargrass (Barros-Rodríguez et al 2012). In this context, (Ruiz-González 2013) reported a significant increase in milk fat content from 3.84 to $4.05 \%$ when the inclusion of L. leucocephala increased from 15 to $30 \%$ in the diet. In agreement to the present study, Hernández Rodríguez (2005) reported an increased milk fat content in the dry season when the cows grazed a silvopastoral system similar to our study (L. leucocephala and C. nlemfuensis).

There was no significant interaction between season and system regarding all milk components which agreed with La Terra et al (2012). The $\mathrm{pH}$ values in the two systems were in the natural range for fresh milk (between 6.5 and 6.8) (Fox and McSweeney 1998). The slight lower $\mathrm{pH}$ in milk during the dry season could be attributed to the increase in the environmental temperature in this season specifically March and April as shown in Fig. 1.

\subsection{Fresh soft cheese composition and yield}

The lack of differences in cheese composition between MS and ISS could be explained by the absence of differences in milk composition between systems. However, there was a significant interaction between the season and the system reflected in a higher adjusted cheese yield from ISS during the rainy season. This result is relevant and means that ISS could be a good option for the cheese maker in tropical areas, especially during the rainy season, where cheese yield has been reported to be lower (Solís-Méndez et al 2013).

Similar results was found by EL-Sheikh et al (2011) who reported higher yield of Domiati cheese $(32.73 \%)$ when using leucaena leafs as a source of $30 \%$ of protein requirements in the feeding system of dairy buffaloes comparing with sunflower meal 
(29.93\%). These values are higher than our values in the present study, while this could be attributed to the differences of the type of milk.

The higher content of milk solids in the dry season, particularly fat and protein was reflected in the cheese percentages of dry matter, fat/DM, protein/DM and adjusted cheese yield which were all higher in the dry season. Hattem et al (2012) stated that the difference in milk casein and fat in total is the major factor responsible for the change in the cheese yield; in addition, seasonal changes have significant impacts on cheese composition and cheese yield. That assumptions have been reported for several types of cheeses such as "Tepeque" cheese, a traditional cheese made in the east of Mexico ( Solís-Méndez et al 2013), Ras cheese in Egypt (Hattem et al 2012) and hard-pressed ovine cheese in the USA (Jaeggi et al 2005).

On the other hand, the absence of differences in the treatments for salt/M \% can be attributed to the fixed percentage of salt used in the cheese making (3\%).

\subsection{Correlation between milk composition and fresh soft cheese yield}

As mentioned before, fat and protein in milk are the main components that affects the cheese yield ( Verdier-Metz et al 2001; Soryal et al 2004; Jaeggi et al 2005; Hattem et al 2012). In MS, fat content was more correlated to the adjusted fresh cheese yield than in ISS. Milk protein and lactose also presented the same trend but with low correlation values. Soryal et al (2004) reported similar results with the same type of cheese but from goat milk. They found that milk fat content was more highly correlated to cheese yield than milk protein content ( $r=0.60$ vs 0.38 , respectively).

\subsection{Sensory evaluation of fresh soft cheese}

Sensory properties of milk can be affected by composition of forage as well as proportion of forage to concentrate. If such type of milk is used for production of dairy products, product composition as well as sensory properties could be affected (Larsen et al 2013). Nozière et al (2006) reported clear effect of consumption of green forages by the cows on the increases of the $\beta$-carotene content in milk and cheese, which is responsible of the yellow color. In this respect, Lamchoun (1998) reported high $\beta$-carotene content of leucaena leaf of $116-161 \mathrm{mg} \cdot \mathrm{kg}^{-1} \mathrm{DM}$ comparing with other types of grass. In the present study, acceptability in the cheese sensory attributes of appearance, color, flavor, and overall acceptability were found to be similar between the ISS and MS during the two grazing seasons. This result could be attributed to the similarity in gross chemical composition of the cheese between the two treatments, especially the fat content, where Soryal et al (2004) associate the adverse effect on the cheese flavor score with milk fat content in fresh Domiati cheese. In another study, Morillo and Faría-Mármol (1996) did not show any significant effect on the odor or the color of the milk when the cows consumed leucaena.

There was found higher texture acceptability $(P<0.05)$ of the cheese from ISS compared with cheese from MS during the dry season. Similar results were reported by EL-Sheikh et al (2011) who found high body and texture score of the fresh soft cheese (Domiati type) when using leucaena leafs as source of $30 \%$ of protein requirements in the feeding system of dairy buffaloes comparing with Sunflower meal. 


\section{Conclusions}

Milk and fresh soft cheese characteristics from the ISS with L. leucocephala and C. nlemfuensis were similar to that produced from the MS of $C$. nlemfuensis. The ISS could be a good alternative to improve cheese yield in the tropics. Cheese from ISS was well accepted and showed higher preference for texture in relation to the cheese from MS.

Acknowledgments The authors are grateful with the financial support of "SAGARPA-CONACYT Proyecto 2011-14-175169" and "Cargas-Leche-SSPi, F.P.M., A.C." This work is a partial requirement for a $\mathrm{Ph} . \mathrm{D}$. degree funded to the first author by the Consejo Nacional de Ciencia y Tecnologia (CONACYT) (grant number 510528) at the Universidad Autónoma de Yucatán, Mexico.

Conflict of interest Asmaa H. M. Mohammed, Carlos F. Aguilar-Pérez, Armín J. Ayala-Burgos, María B. Bottini-Luzardo, Francisco J. Solorio-Sánchez, and Juan C. Ku-Vera declare that they have no conflict of interest.

\section{References}

AFRC (1993) Energy and protein requirements of ruminants: an advisory manual prepared by the AFRC Technical Committee on Responses to Nutrients. CAB International

AOAC (2012) Official methods of analysis, Association of Official Analytical Chemists, Gaithersburg, USA, 19 th edn

Ayala A, Honhold N, Delgado R, Magaña J (1992) A visual condition scoring scheme for bos indicus and crossbred cattle. In: Anderson S and Wadsworth J, (ed.) Dual purpose cattle production research. Proceedings of IFS/FMVZUADY International Workshop; 1992 Mar. 23-27; Mérida. Yucatán, México

Barros-Rodríguez M, Solorio-Sánchez J, Ku-Vera J, Ayala-Burgos A, Sandoval-Castro C, Solís-Pérez G (2012) Productive performance and urinary excretion of mimosine metabolites by hair sheep grazing in a silvopastoral system with high densities of Leucaena leucocephala. Trop Anim Health Prod 44:18731878

Bottini-Luzardo MB (2015) Caracterización y evaluacion del ciclo estral, función ovárica y medio ambiente uterino en vacas multíparas consumiendo Leucaena leucocephala en el trópico mexicano (Characterization and evaluation of the estrous cycle, ovarian function and uterine environment in multiparous cows consuming Leucaena leucocephala in the Mexican tropics). Ph.D. thesis, UADY Univ., Yucatan, Mexico

Coulon J, Priolo A (2002) La qualité sensorielle des produits laitiers et de la viande dépend des fourrages consommés par les animaux (Sensory properties of meat and dairy products are affected by the forages consumed by the animals). INRA Prod Anim 15:333-342

Cuartas-Cardona CA, Naranjo-Ramírez JF, Tarazona-Morales AM, Enrique-Murgueitio R, Chará-Orozco JD, Ku-Vera J, Solorio-Sánchez FJ, Flores-Estrada MX, Solorio-Sánchez B, Barahona-Rosales R (2014) Contribution of intensive silvopastoral systems to animal performance and to adaptation and mitigation of climate change. Rev Colomb Ciencias Pecu 27:76-94

Delahunty CM, Drake MA (2004) Sensory character of cheese and its evaluation. In: Fox P, McSweeney P, Cogan T, Guinee T (eds) Cheese: chemistry, physics and microbiology, vol 1. Elsevier Academic Press, Amsterdam, pp 455-487

Dove H, Mayes R (1991) The use of plant wax alkanes as marker substances in studies of the nutrition of herbivores: a review. Aust J Agric Res 42:913

Echevarría MER, Corral-Flores G, Solorio-Sánchez B, Alarcón-Rojo AD, Grado-Ahuir JA, Rodríguez-Muela C, Palacios LC, Beltrán VES, Solorio-Sánchez FJ (2013) Calidad de la carne de bovinos engordados en un sistema silvopastoril intensivo en dos epocas del año (Meat quality from cattle fattened in intensive silvopastoril system in two seasons of the year). Trop Subtrop Agroecosystems 16:235-241, 12 
EL-Sheikh MM, Abo EL-Nor SAH, Shahein NM, Abd-Rabou NS (2011) Effect of protein feeding system on the quality of milk and its resultant Domiati Cheese. J Am Sci 7:282-290

FAO (2013) Food outlook: Milk and milk products. Available from http://www.fao.org/fileadmin/templates/ est/COMM_MARKETS_MONITORING/Dairy/Documents/November_2013.pdf

Faría-Mármol J, Chirinos Z, Morillo DE (2007) la sustitución parcial del alimento concentrado por pastoreo con Leucaena leucocephala sobre la producción y características de la leche y variación de peso vacas mestizas (Effect of partial substitution of concentrate feed by grazing with Leucaena leucocephala on the production and characteristics of milk, and liveweight change of crossbred cows). Zootec Trop 25:245251

Fox PF, McSweeney PLH (1998) Dairy chemistry and biochemistry. Blackie academic \& professional, UK

García E (1988) Modificaciones al Sistema de Clasificación Climática de Köppen, para adaptarlo a las condiciones de la República Mexicana. Instituto de Geografía. Universidad Nacional Autónoma de México. D. F., México

Hattem HE, Taleb AT, Manal AN, Hanaa SS (2012) Effect of pasteurization and season on milk composition and ripening of Ras cheese. J Brew Distill 3:15-22

Hernández Rodríguez R (2005) Efecto de la época del año sobre el comportamiento de la producción y la composición de la leche en tres genotipos bajo silvopastoreo (Effect of season on milk production and composition from three cattle genotypes under silvo-pastoral conditions). Livest Res Rural Dev 17(12)

Hernández Rodríguez R, Ponce Ceballo P (2004) Efecto del silvopastoreo como sistema sostenible de explotación bovina sobre la composición de la leche (Effect of silvopastoral production systems on composition of milk from cattle). Livest Res Rural Dev 16:55-59

Jaeggi JJ, Wendorff WL, Romero J et al (2005) Impact of seasonal changes in ovine milk on composition and yield of a hard-pressed cheese. J Dairy Sci 88:1358-1363

Kleyn DH, Lynch JM, Barbano DM, Bloom MJ, Mitchell MW (2001) Determination of fat in raw and processed milks by the gerber method: collaborative study. J AOAC Int 84:1499-1508

La Terra S, Marino VM, Schadt I, Caccamo M, Azzaro G, Carpino S, Licitra G (2012) Influence of season and pasture feeding on the content of CLA isomers in milk from three different farming systems in Sicily. Dairy Sci Technol 93:1-10

LACTODATA (2015) Informacion sobre el sector lechero (Information about the dairy sector). Available from http://www.lactodata.com/lactodata/docs/ind/lacto_ind_prod.pdf

Lamchoun W (1998) Seasonal Variation and effect of Sources of Beta-carotene on Plasma Beta-carotene concentration of Dairy Cattle. M.Sc. Thesis, Chiang Mai University, Chiang Mai, Thailand

Larsen MK, Kidmose U, Kristensen T, Beaumont P, Mortensen G (2013) Chemical composition and sensory quality of bovine milk as affected by type of forage and proportion of concentrate in the feed ration. J Sci Food Agric 93:93-99

LECO Corporation (2014) TruMac CN determinator. Instruction Manual. LECO Corporation, Saint Joseph

MAFF (Ministry of Agriculture, Fisheries and Food) (1975) Energy allowance and feeding system for ruminants. Technical Bulletin, Her Majesty's Stationery Office, London

Mehaia MA (2006) Manufacture of fresh soft white cheese (Domiati type) from dromedary camel's milk using ultrafiltration process. J Food Technol 4:206-212

Morillo DE, Faría-Mármol J (1996) Efecto del suministro de Leucaena leucocephala (lam.) De Wit y/o de afrecho húmedo de cebada sobre la producción y algunas propiedades de la leche de vacas mestizas (Effect of feeding Leucaena leucocephala (Lam.) De Wit and/or wet brewers grains on production and some properties of milk of crossbred cows. Revista Cientifica-FCV-LUZ 6:149-154

Nahed-Toral J, Sanchez-Muñoz B, Mena Y, Ruiz-Rojas J, Aguilar-Jimenez R, Castel JM, de Asis Ruiz F, Orantes-Zebadua M, Manzur-Cruz A, Cruz-Lopez J, Delgadillo-Puga C (2013) Feasibility of converting agrosilvopastoral systems of dairy cattle to the organic production model in southeastern Mexico. J Clean Prod 43:136-145

Nielsen SS (2010) Sodium determination using ion selective electrodes, Mohr titration, and test strips. In food analysis laboratory manual. Springer Science \& Business Media, USA

Nozière P, Graulet B, Lucas A, Martin B, Grolier P, Doreau M (2006) Carotenoids for ruminants: from forages to dairy products. Anim Feed Sci Technol 131:418-450

O'Connell JE, Fox PF (2001) Significance and applications of phenolic compounds in the production and quality of milk and dairy products: a review. Int Dairy J 11:103-120

OECD/FAO (2013) OECD-FAO Agricultural Outlook 2013-2022. Available from http://www.oecd-ilibrary. org/agriculture-and-food/oecd-fao-agricultural-outlook-2013_agr_outlook-2013-en

OECD/FAO (2014) OECD/Food and Agriculture Organization of the United Nations Agricultural Outlook 2014. OECD Publishing. Available from http://www.oecd-ilibrary.org/agriculture-and-food/oecd-faoagricultural-outlook-2014_agr_outlook-2014-en

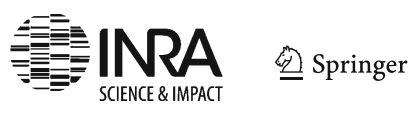


Pedraza-Beltrán P, Estrada-Flores JG, Martínez-Campos AR, Estrada-López I, Rayas-Amor AA, Yong-Angel G, Figueroa-Medina M, Nova FA, Castelán-Ortega OA (2012) On-farm evaluation of the effect of coffee pulp supplementation on milk yield and dry matter intake of dairy cows grazing tropical grasses in central Mexico. Trop Anim Health Prod 44:329-336

Peniche-González IN, González-López ZU, Aguilar-Pérez CF, Ku-Vera JC, Ayala-Burgos AJ, SolorioSánchez FJ (2014) Milk production and reproduction of dual-purpose cows with a restricted concentrate allowance and access to an association of Leucaena leucocephala and Cynodon nlemfuensis. J Appl Anim Res 42:345-351

Rojo-Rubio R, Vázquez-Armijo JF, Pérez-Hernández P, Mendoza-Martínez GD, Salem AZM, AlbarránPortillo B, González-Reyna A, Hernández-Martínez J, Rebollar-Rebollar S, Cardoso-Jiménez D, Dorantes-Coronado EJ, Gutierrez-Cedillo JG (2008) Dual purpose cattle production in Mexico. Trop Anim Health Prod 41:715-721

Ruiz-González A (2013) Balance de nitrógeno y composición de leche de vacas alimentadas con Leucaena leucocephala (Nitrogen balance and composition of milk from cows fed Leucaena leucocephala). MSc thesis. UADY Univ. Yucatan, México

SAGARPA/SIAP (2014) Panorama de la lechería en México. Available from http://www.siap.gob.mx/wpcontent/uploads/boletinleche/bboletleche1 trim2014.pdf

Solís-Méndez AD, Martínez-Loperena R, Solorio-Sánchez J, Estrada-Flores JG, Avilés-Nova F, GutiérrezIbáñez AT, Castelán-Ortega OA (2013) Características del queso tepeque de la tierra caliente de michoacán: un queso producido en un sistema silvopastoril intensivo (Characteristics of the tepeque cheese from "la tierra caliente" of the state of Michoacán: a cheese produced in an intensive silvopastoral system). Trop Subtrop Agroecosystems 16:201-214

Soryal KA, Zeng SS, Min BR, Hart SP, Beyene FA (2004) Effect of feeding systems on composition of goat milk and yield of Domiati cheese. Small Rumin Res 54:121-129

SPSS for windows (2013) Statistical package for the social sciences, version 22,0. SPSS Inc., USA

Stobbs TH, Fraser JS (1971) Composition and processing quality of milk produced from cows grazing some tropical pasture species. Aust J Dairy Technol 26:100-104

Tejada I (1983) Manual de laboratorio para análisis de ingredientes utilizados en alimentación animal. Instituto de Investigaciones Pecuarias, México

Todaro M, Bonanno A, Scatassa ML (2014) The quality of Valle del Belice sheep's milk and cheese produced in the hot summer season in Sicily. Dairy Sci Technol 94:225-239

Van Soest PJ, Robertson JB, Lewis BA (1991) Methods for dietary fiber, neutral detergent fiber, and nonstarch polysaccharides in relation to animal nutrition. J Dairy Sci 74:3583-3597

Verdier-Metz I, Coulon J-B, Pradel P (2001) Relationship between milk fat and protein contents and cheese yield. Anim Res 50:365-371

Von Borell E, Sørensen JT (2004) Organic livestock production in Europe: aims, rules and trends with special emphasis on animal health and welfare. Livest Prod Sci 90:3-9 